\title{
Platelet inhibition and clinical outcomes of low dose ticagrelor in patients with coronary artery disease: a meta-analysis of randomized controlled trials
}

\author{
Cheng Xie ( $\nabla$ xiecheng_1999@163.com ) \\ The First Affiliated Hospital of Soochow University https://orcid.org/0000-0002-6681-3405 \\ Xiaoliang Ding \\ First Affiliated Hospital of Soochow University \\ Qiong Qin \\ First Affiliated Hospital of Soochow University \\ Jia Lin \\ First Affiliated Hospital of Soochow University \\ Yuzhen Zhang \\ First Affiliated Hospital of Soochow University
}

\section{Research Article}

Keywords: Ticagrelor, Low dose, Coronary artery disease, Randomized controlled trial, Meta-analysis

Posted Date: April 14th, 2021

DOl: https://doi.org/10.21203/rs.3.rs-418616/v1

License: (c) (i) This work is licensed under a Creative Commons Attribution 4.0 International License. Read Full License 


\section{Abstract \\ Background}

Although current guidelines recommend ticagrelor $90 \mathrm{mg}$ twice daily in ACS patients for 12 months and $60 \mathrm{mg}$ twice daily in stable patients 1 to 3 years after MI with additional high-risk features, the bleeding complication was actually higher than clopidogrel. This metaanalysis was performed to assess the platelet inhibition and clinical outcomes of low dose ticagrelor in patients with CAD.

\section{Methods}

Medline, EMBASE and Cochrane Databases were systematically searched from inception to March, 2021 for randomized controlled trials (RCTs) comparing low dose ticagrelor with standard dose clopidogrel or standard dose ticagrelor in patients with CAD. Pooled estimates were calculated using fixed-effects or random-effects model as appropriate.

\section{Results}

15 RCTs that included 15357 patients were identified. Low dose ticagrelor had no statistical differences of the risks of MACE and major bleeding compared with standard dose ticagrelor and standard dose clopidogrel (RR 0.98,95\% $\mathrm{Cl} 0.87-1.11, \mathrm{P}=0.80 ; \mathrm{RR} 1.35,95 \% \mathrm{Cl} 0.46$ - 4.00, $\mathrm{P}=0.59 ; \mathrm{RR} 0.86,95 \% \mathrm{Cl} 0.68-1.10, \mathrm{P}=0.23 ; \mathrm{RR} 1.46,95 \% \mathrm{Cl} 0.45-4.76, \mathrm{P}=0.53$, respectively). Compared with standard dose clopidogrel, low dose ticagrelor showed significantly lower platelet reaction units (PRU) (MD -118.48, 95\%Cl-144.33--92.63, P $\otimes 0.00001$ ), rates of high on-treatment platelet reactivity (HTPR) (RR $0.10,95 \% \mathrm{Cl} 0.04-0.21, \mathrm{P} \otimes 0.00001)$ and minor or minimal bleeding (RR 0.73 , $95 \% \mathrm{Cl} 0.55-0.96, \mathrm{P}=0.03$ ), but increased the incidence of dyspnea (RR $6.48,95 \% \mathrm{Cl} 1.78-23.54, \mathrm{P}=0.005)$. Compared with standard dose ticagrelor, low dose ticagrelor showed significantly higher PRU (MD 15.45, 95\% $\mathrm{Cl} 5.45-25.44, \mathrm{P}=0.002)$ and risk of dyspnea (RR $0.81,95 \% \mathrm{Cl} 0.75-0.88, \mathrm{P} \otimes 0.00001)$, but similar rates of HTPR (RR $1.63,95 \% \mathrm{Cl} 0.40-6.70, \mathrm{P}=0.50)$ and minor or minimal bleeding (RR $1.36,95 \% \mathrm{Cl} 0.78-2.38, \mathrm{P}=0.28)$.

\section{Conclusion}

Low dose ticagrelor may provide an additional choice for secondary prevention in CAD patients. However, the specific dose of ticagrelor should be selected according to the patients' clinical characteristics.

\section{Introduction}

Coronary artery disease (CAD) is a pathological process characterized by atherosclerotic plaque accumulation in the epicardial arteries, whether obstructive or non-obstructive. The disease can have long, stable periods but can also become unstable at any time, typically due to an acute atherothrombotic event caused by plaque rupture or erosion. The dynamic nature of the CAD process results in various clinical presentations, which can be conveniently categorized as either acute coronary syndromes (ACS) or chronic coronary syndromes (CCS) ${ }^{[1]}$.

Ticagrelor is a reversible non-thienopyridine oral $\mathrm{P}_{2} \mathrm{Y}_{12}$ inhibitor that provides faster, more potent and consistent platelet inhibition than clopidogrel ${ }^{[2]}$. The PLATO trial demonstrated in patients who have an ACS, treatment with ticagrelor $90 \mathrm{mg}$ twice daily as compared with clopidogrel $75 \mathrm{mg}$ once daily significantly reduced the rate of ischemic complications without an increase in the rate of overall major bleeding ${ }^{[3]}$. In the PEGASUS-TIMI 54 study of post-MI patients with additional high-risk features and low bleeding risks, the benefit-to-risk profile appears to be numerically more favorable for ticagrelor $60 \mathrm{mg}$ twice daily ${ }^{[4]}$. In this, the current guidelines recommend ticagrelor 90 $\mathrm{mg}$ twice daily in ACS patients for 12 months and $60 \mathrm{mg}$ twice daily in MI patients with high ischaemic-risk who have tolerated dual antiplatelet therapy (DAPT) without a bleeding complication for longer than 12 months ${ }^{[5-7]}$.

However, antithrombotic therapy for patients with CAD is a long-term management. The optimal antiplatelet therapy aims to prevent thrombosis while avoiding hemorrhage. To account for this, different strategies have been proposed, such as de-escalation strategy ${ }^{[8]}$ and platelet function ${ }^{[9]}$ or genotype-guided strategy ${ }^{[10]}$. Recently, several studies have displayed low dose ticagrelor could provide better safety and tolerability than standard usage of ticagrelor while achieving greater and more consistent platelet inhibition than standard usage of clopidogrel ${ }^{[11-13]}$. Therefore, we conducted a meta-analysis to assess the platelet inhibition and clinical outcomes of low dose ticagrelor in patients with CAD. 


\section{Methods}

\section{Literature Search}

This meta-analysis was conducted according to the Preferred Reporting Items for Systematic Reviews and Meta-Analyses (PRISMA) statement. We systematically searched Medline, EMBASE and Cochrane Databases for all relevant articles comparing low dose ticagrelor with standard dose clopidogrel or standard dose ticagrelor in patients with CAD through March, 2021. Literature was searched with the following keywords: ticagrelor, AZD6140, AZD 6140, AZD-6140, 30, 45, 60, quarter, half, low, reduced, once, coronary disease, coronary artery disease, coronary heart disease, acute coronary syndrome, myocardial infarction, unstable angina, chronic coronary syndromes and random*. A comprehensive search of reference lists of all review articles and original studies retrieved by this method was performed to identify additional studies.

\section{Selection criteria}

The inclusion criteria were the following: (1) trials designed as RCT; (2) trials based on patients with CAD; (3) trials compared low dose ticagrelor with standard dose clopidogrel or standard dose ticagrelor; (4) trials reported outcomes included platelet inhibition, ischemic events or bleeding events.

\section{Data Abstraction}

Two investigators (Cheng Xie and Xiaoliang Ding) independently assessed studies for possible inclusion by reading titles and/or abstracts, then viewed the full-texts of the remaining publications to pick up the ultimately available studies. Data extraction was done by one reviewer (Cheng Xie), and subsequently cross-checked by the other reviewer (Xiaoliang Ding). Any divergences were discussed or determined by a third investigator (Qiong Qin). Following information was abstracted: the first author and publication year, country, sample size, baseline features of patients, intervention features, follow-up time, platelet inhibition and clinical outcomes and their definitions.

\section{Bias Risk and Study Quality Assessment}

The methodological quality of eligible studies was assessed by the Cochrane collaboration's tool for assessing risk of bias including the following criteria: sequence generation, allocation concealment, blinding, incomplete outcome data, selective outcome reporting, and other issues. The bias risk of each study was scored as low, unclear, or high in each section.

\section{Statistical Analysis}

Dichotomous data were expressed risk ratio (RR) with $95 \%$ confidence interval $(\mathrm{Cl})$. Continuous data were expressed as mean difference (MD). Heterogeneity of effect size across the studies was tested using $Q$ statistics at the $P<0.10$ level of significance. We also calculated the $\mathrm{I}^{2}$ statistic with a quantitative measure of inconsistency across the studies. The data were pooled by random-effects model in case significant heterogeneity (Cochran test with $\mathrm{P}<0.10$ or $\mathrm{I}^{2}>50 \%$ ) was found. Otherwise, the fixed-effects model was used. Sensitivity analyses with fixed-effect models were performed to assess consistency among effect estimates that were obtained with random- and fixed-effects models. Meta-analysis was performed with the software of Cochrane Review Manager 5.1.2 (Cochrane Library Software, Oxford, UK).

\section{Results}

\section{Study selection and study characteristics}

Fig. 1 shows a flow diagram for the selection process. A total of $15 \mathrm{RCTs}^{[4,11-24]}$ that included 15357 patients (low dose ticagrelor $=7582$, standard dose ticagrelor $=416$, standard dose clopidogrel $=7445$ ) were finally identified. Table 1 summarizes the characteristics of the selected studies. Among the 15 RCTs, ten studies were based on patients from East Asia ${ }^{[11,15-18,21,22-24]}$ and the others were from Poland ${ }^{[13]}$, Greece ${ }^{[20]}$, United Kingdom and United States ${ }^{[4,12,19]}$. The low doses of ticagrelor investigated in these studies were different, six studies used $60 \mathrm{mg}$ twice daily $[4,11,12,13,19,20,22]$, five studies used $45 \mathrm{mg}$ twice daily $[14,15,17,23,24]$, the other four studies used $22.5 \mathrm{mg}$ twice daily [16], $60 \mathrm{mg}$ once daily [22], $45 \mathrm{mg}$ twice daily and $60 \mathrm{mg}$ twice daily ${ }^{[18]}$, and $45 \mathrm{mg}$ twice daily and $90 \mathrm{mg}$ once daily ${ }^{[21]}$, respectively. The characteristics of the included studies were shown in Tab. 1. Quality assessments for studies are reported in Supplemental Fig. S1 and S2. 
13 studies reported platelet inhibition ${ }^{[11-22,24]}$ and VerifyNow P2Y12 assay was the most widely reported method ${ }^{[11,12,16,17,19-22]}$. Pooled analysis indicated that compared with standard dose ticagrelor, low dose ticagrelor showed significantly higher platelet reaction units (PRU) (MD 15.45, 95\% Cl 5.45-25.44, P = 0.002). Even so, the PRU of low dose ticagrelor was significantly lower than standard dose clopidogrel (MD -118.48, 95\% Cl-144.33--92.63, P ख0.00001) (Fig. 2).

9 studies reported the rates of high on-treatment platelet reactivity (HTPR) ${ }^{[11-13,16,17,19-22]}$. Pooled analysis indicated that low dose ticagrelor had similar rate of HTPR compared with standard dose ticagrelor (RR 1.63, 95\% $\mathrm{Cl} 0.40-6.70, \mathrm{P}=0.50)$, but significantly lower than standard dose clopidogrel (RR 0.10, 95\% Cl 0.04-0.21, P $\otimes 0.00001$ ) (Fig. 3).

\section{Clinical efficacy}

6 studies $[4,12,13,20,23,24]$ reported major adverse cardiovascular events (MACE). Pooled analysis indicated that compared with standard dose ticagrelor and standard dose clopidogrel, low dose ticagrelor had similar risk of MACE (RR 0.98, 95\% $\mathrm{Cl} 0.87-1.11, \mathrm{P}=0.80$ and RR $1.35,95 \% \mathrm{Cl} 0.46-4.00, \mathrm{P}=0.59$, respectively) (Fig. 4).

\section{Clinical safety}

13 studies ${ }^{[4,12-18,20-24]}$ reported bleeding events. Pooled analysis indicated that compared with standard dose ticagrelor and standard dose clopidogrel, low dose ticagrelor had similar risk of major bleeding ( $R R 0.86,95 \% \mathrm{Cl} 0.68-1.10, \mathrm{P}=0.23$ and $\mathrm{RR} 1.46,95 \% \mathrm{Cl} 0.45-4.76$, $\mathrm{P}=0.53$, respectively) (Fig. 5). In terms of minor or minimal bleeding, low dose ticagrelor significantly reduced the incidence compared with standard dose ticagrelor ( $R R 0.73,95 \% \mathrm{Cl} 0.55-0.96, \mathrm{P}=0.03$ ). Meanwhile, it did not significantly increase the incidence compared with standard dose clopidogrel (RR 1.36, 95\% Cl 0.78-2.38, $\mathrm{P}=0.28$ ) (Fig. 6).

12 studies ${ }^{[4,12-18,20-22,24]}$ reported the adverse drug reaction of dyspnea. Pooled analysis indicated that compared with standard dose ticagrelor, low dose ticagrelor significantly reduced the incidence of dyspnea (RR $0.81,95 \% \mathrm{Cl} 0.75-0.88, \mathrm{P} \otimes 0.00001$ ), but compared with standard dose clopidogrel it significantly increased the incidence (RR $6.48,95 \% \mathrm{Cl} 1.78-23.54, \mathrm{P}=0.005)(\mathrm{Fig} .7)$.

\section{Sensitivity analyses}

There was no difference in the results between the fixed-effect model and the random-effect model for the platelet inhibition and clinical outcomes.

\section{Discussion}

Antiplatelet agents are the cornerstone of secondary prevention in patients with CAD. Ticagrelor has the most predictable and consistently high level of P2Y12 inhibition during maintenance therapy, and also has more rapid onset, as well as more rapid and predictable offset of action compared with clopidogrel ${ }^{[25,26]}$. How to reduce thrombotic complications while minimizing the occurrence of bleeding and other adverse events is the hotspot of current antiplatelet therapy. In this meta-analysis, we assessed the platelet inhibition and clinical outcomes of low dose ticagrelor in patients with CAD. The main findings of this meta-analysis were as follows: (1) Although the PRU of low dose ticagrelor was significantly higher than standard dose ticagrelor, the rate of HTPR was similar, and both of them were significantly lower than standard dose clopidogrel. (2) Compared with standard dose ticagrelor and standard dose clopidogrel, low dose ticagrelor had similar risks of MACE and major bleeding, but the incidence of minor or minimal bleeding was significantly lower than standard dose ticagrelor. (3) The rate of dyspnea of low dose ticagrelor was significantly lower than standard dose ticagrelor, but significantly higher than standard dose clopidogrel.

Plaque rupture and thrombosis are the major concerns in patients with CAD, and excessive platelet activation and aggregation are central to the pathogenesis of CAD. Although correlations between various platelet function assays were not robust, the most widely used assays such as VerifyNow P2Y12 assay have overcome many of the technical and methodological limitations of previous assays ${ }^{[27,28]}$. In the past decades, compelling evidence from numerous observational studies has emerged demonstrating a strong association between HTPR and ischemic events ${ }^{[29,30]}$.

Bleeding, as the most common side effects of ticagrelor, has been well evaluated in previous studies. Although both the PLATO trial ${ }^{[3]}$ and PEGASUS-TIMI 54 trial ${ }^{[4]}$ demonstrated ticagrelor achieved greater reduction of MACE, at the expense of more non-fatal bleeding and dyspnoea. The recent completion of RCTs comparing ticagrelor with clopidogrel, specifically dedicated to the evaluation of those 


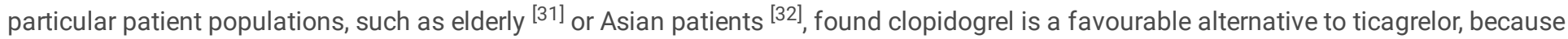
it leads to fewer bleeding events without an increase in the combined endpoint of MACE. Combined with the results of our meta-analysis, low dose ticagrelor may provide an additional antiplatelet strategy to balance the risk of ischemia and bleeding.

Dyspnea was another important side effect of ticagrelor. The PLATO trial showed that dyspnea was more common in the ticagrelor group than in the clopidogrel group (13.8\% vs. $7.8 \%, \mathrm{P} \otimes 0.001)$ and more patients discontinued treatment $(0.9 \%$ vs. $0.1 \%, \mathrm{P} \otimes 0.001)$. Zhang et al. did a meta-analysis including 21 RCTs showed ticagrelor was associated with an increased risk of dyspnea compared with clopidogrel (RR 2.15, 95\% Cl 1.59-2.92, P $\otimes 0.01$ ) and was consistent in subgroups with different follow-up durations ${ }^{[33]}$. On the other hand, the DISPERSE ${ }^{[34]}$ and DISPERSE-2 ${ }^{[35]}$ trial reported that the increased rate of dyspnea was dose-dependent. These results were consistent with our meta-analysis.

We acknowledge our meta-analysis had several limitations. First, various low doses of ticagrelor were included. Second, because of limited data, patients with ACS and CCS were pooled together. Third, given the limited number of studies included in the analysis, our findings should be confirmed with future research.

\section{Conclusions}

Low dose ticagrelor may provide an additional choice for secondary prevention in CAD patients. However, the specific dose of ticagrelor should be selected according to the patients' clinical characteristics.

\section{Declarations}

\section{Authors contribution}

$\mathrm{CX}$ and $\mathrm{YZ}$ contributed to the conception or design of the work. CX, XD and QQ contributed to the acquisition, analysis, or interpretation of data for the work. CX and XD drafted the manuscript. JL and $Y Z$ critically revised the manuscript. All gave final approval and agree to be accountable for all aspects of work ensuring integrity and accuracy.

\section{Acknowledgment}

None.

\section{Funding}

No external funding was used for this research.

\section{Data Availability Statement}

Data sharing is not applicable to this article as no new data were created or analyzed in this study.

\section{Compliance with Ethical Standards}

\section{Conflict of Interest}

The authors declare that they have no conflict of interests regarding the publication of this manuscript.

\section{Ethical}

Approval Not required.

\section{References}

1. Knuuti J, Wijns W, Saraste A, Capodanno D, Barbato E, Funck-Brentano C, et al. 2019 ESC Guidelines for the diagnosis and management of chronic coronary syndromes. Eur Heart J. 2020;41(3):407-77. http://doi:10.1093/eurheartj/ehz425.

2. Storey RF, Angiolillo DJ, Patil SB, Desai B, Ecob R, Husted S, et al. Inhibitory effects of ticagrelor compared with clopidogrel on platelet function in patients with acute coronary syndromes: the PLATO (PLATelet inhibition and patient Outcomes) PLATELET substudy. J Am Coll Cardiol. 2010;56(18):1456-62. http://doi:10.1016/j.jacc.2010.03.100. 
3. Wallentin L, Becker RC, Budaj A, Cannon CP, Emanuelsson H, Held C, et al. Ticagrelor versus clopidogrel in patients with acute coronary syndromes. N Engl J Med. 2009;361(11):1045-57. http://doi:10.1056/NEJMoa0904327.

4. Bonaca MP, Bhatt DL, Cohen M, Steg PG, Storey RF, Jensen EC, Magnani G, Bansilal S, Fish MP, Im K, et al. Long-term use of ticagrelor in patients with prior myocardial infarction. N Engl J Med. 2015;372(19):1791-800. http://doi:10.1056/NEJMoa1500857.

5. Ibanez B, James S, Agewall S, Antunes MJ, Bucciarelli-Ducci C, Bueno H, et al. 2017 ESC guidelines for the management of acute myocardial infarction in patients presenting with ST-segment elevation: The Task Force for the management of acute myocardial infarction in patients presenting with ST-segment elevation of the European Society of Cardiology (ESC). Eur Heart J. 2018;39(2):119-77. http://doi:10.1093/eurheartj/ehx393.

6. Levine GN, Bates ER, Bittl JA, Brindis RG, Fihn SD, Fleisher LA, et al. 2016 ACC/AHA guideline focused update on duration of dual antiplatelet therapy in patients with coronary artery disease: a report of the American College of Cardiology/American Heart Association Task Force on Clinical Practice Guidelines. J Am Coll Cardiol. 2016;68(10):1082-115. http://doi:10.1016/j.jacc.2016.03.513.

7. Section of Interventional Cardiology of Chinese Society of Cardiology, Section of Atherosclerosis and Coronary Artery Disease of Chinese Society of Cardiology, Specialty Committee on Prevention and Treatment of Thrombosis of Chinese College of Cardiovascular Physicians. Guideline on the diagnosis and treatment of stable coronary artery disease. Zhonghua Xin Xue Guan Bing Za Zhi. 2018;46(9):680-94. http://doi:10.3760/cma.j.issn.0253-3758.2018.09.004.

8. Sibbing D, Aradi D, Jacobshagen C, Gross L, Trenk D, Geisler T, Orban M, Hadamitzky M, Merkely B, Kiss RG, et al. Guided de-escalation of antiplatelet treatment in patients with acute coronary syndrome undergoing percutaneous coronary intervention (TROPICAL-ACS): a randomised, open-label, multicentre trial. Lancet. 2017;390(10104):1747-57. http://doi:10.1016/S0140-6736(17)32155-4.

9. Zheng YY, Wu TT, Yang Y, Hou XG, Gao Y, Chen Y, Yang YN, Li XM, Ma X, Ma YT, et al. Personalized antiplatelet therapy guided by a novel detection of platelet aggregation function in stable coronary artery disease patients undergoing percutaneous coronary intervention: a randomized controlled clinical trial. Eur Heart J Cardiovasc Pharmacother. 2020;6(4):211-21. http://doi:10.1093/ehjcvp/pvz059.

10. Claassens DMF, Vos GJA, Bergmeijer TO, Hermanides RS, van 't Hof AWJ, van der Harst P, Barbato E, Morisco C, Tjon Joe Gin RM, Asselbergs FW, et al. A genotype-guided strategy for oral P2Y 12 inhibitors in primary PCI. N Engl J Med. 2019;381(17):1621-31. http://doi:10.1056/NEJMoa1907096.

11. Park DW, Lee PH, Jang S, Lim HS, Kang DY, Lee CH, Ahn JM, Yun SC, Park SW, Park SJ. Effect of low-dose versus standard-dose ticagrelor and clopidogrel on platelet inhibition in acute coronary syndromes. J Am Coll Cardiol. 2018;71(14):1594-5. http://doi:10.1016/j.jacc.2018.02.010.

12. Orme RC, Parker WAE, Thomas MR, Judge HM, Baster K, Sumaya W, Morgan KP, McMellon HC, Richardson JD, Grech ED, et al. Study of two dose regimens of ticagrelor compared with clopidogrel in patients undergoing percutaneous coronary intervention for stable coronary artery disease (STEEL-PCI). Circulation. 2018;138(13):1290-300. http://doi:10.1161/CIRCULATIONAHA.118.034790.

13. Kubica J, Adamski P, Buszko K, Barańska M, Sikora J, Marszałł MP, Sobczak P, Sikora A, Kuliczkowski W, Fabiszak T, et al. Platelet inhibition with standard vs. lower maintenance dose of ticagrelor early after myocardial infarction (ELECTRA): a randomized, openlabel, active-controlled pharmacodynamic and pharmacokinetic study. Eur Heart J Cardiovasc Pharmacother. 2019;5(3):13948.http://doi:10.1093/ehjcvp/pvz004.

14. Hiasa Y, Teng R, Emanuelsson H. Pharmacodynamics, pharmacokinetics and safety of ticagrelor in Asian patients with stable coronary artery disease. Cardiovasc Interv Ther. 2014;29(4):324-33. http://doi:10.1007/s12928-014-0277-1.

15. Li K, Xu Y, Han Q. Safety and efficacy of low-dose ticagrelor in patients with unstable angina pectoris and non-revascularization. Chinese Journal of New Drug. 2015;24(21):2480-4.

16. He M, Liu B, Sun D, Pan Y, Zheng W, Shi J, Zhao S, Dong X, Lu S, Li M, et al. One-quarter standard-dose ticagrelor better than standarddose clopidogrel in Chinese patients with stable coronary artery disease: a randomized, single-blind, crossover clinical study. Int $\mathrm{J}$ Cardiol. 2016;215:209-13. http://doi:10.1016/j.jjcard.2016.04.087.

17. Xue HJ, Shi J, Liu B, Wang DY, Dong ZX, Guo H, Kong YH, Sheng L, Shao Q, Sun DH, et al. Comparison of half- and standard-dose ticagrelor in Chinese patients with NSTE-ACS. Platelets. 2016;27(5):440-5. http://doi:10.3109/09537104.2015.1135890.

18. Li H, Guo J, Carlson GF, Teng R. Pharmacodynamics, pharmacokinetics, and safety of ticagrelor in Chinese patients with stable coronary artery disease. Br J Clin Pharmacol. 2016;82(2):352-61. http://doi:10.1111/bcp.12950.

19. Storey RF, Angiolillo DJ, Bonaca MP, Thomas MR, Judge HM, Rollini F, et al. Platelet inhibition with ticagrelor 60 mg versus 90 mg twice daily in the PEGASUS-TIMI 54 trial. J Am Coll Cardiol. 2016;67(10):1145-54. http://doi:10.1016/j.jacc.2015.12.062. 
20. Alexopoulos D, Despotopoulos S, Xanthopoulou I, Davlouros P. Low-dose ticagrelor versus clopidogrel in patients with prior myocardial infarction. J Am Coll Cardiol. 2017;70(16):2091-2. http://doi:10.1016/j.jacc.2017.08.031.

21. Choi KN, Jin HY, Shin HC, Park YA, Seo JS, Jang JS, Yang TH, Kim DK, Kim DS. Comparison of the antiplatelet effects of once and twice daily low-dose ticagrelor and clopidogrel after percutaneous coronary intervention. Am J Cardiol. 2017;120(2):201-6. http://doi:10.1016/j.amjcard.2017.04.010.

22. He M, Zhang Y, Yan W, Liu G, Sun D, Yuan Y, Shi J, Kong Y, Li Y. 60 mg dose ticagrelor provides stronger platelet inhibition than clopidogrel in Chinese patients with chronic coronary syndrome: a randomized, single-blind, crossover study. Thromb Res. 2020;190:60-1. http://doi:10.1016/j.thromres.2020.03.014.

23. Xue J, Li M, Wang L, Ma M, Zhang J. Comparison of the efficacy of half ticagrelor loading doses and clopidogrel in elderly acute coronary syndrome patients in China. Tropical Journal of Pharmaceutical Research. 2020;19(3):661-6. http://doi:10.4314/tjpr.v19i3.29.

24. Wang Y, Jiang Y, Zhi W, Fu Y, Wang Q, Zhou J, Zheng S, Hao G. Safety and feasibility of low-dose ticagrelor in patients with STsegment elevation myocardial infarction. Clin Cardiol. 2021;44(1):123-8. http://doi:10.1002/clc.23517.

25. Gurbel PA, Bliden KP, Butler K, Tantry US, Gesheff T, Wei C, et al. Randomized double-blind assessment of the ONSET and OFFSET of the antiplatelet effects of ticagrelor versus clopidogrel in patients with stable coronary artery disease: the ONSET/OFFSET study. Circulation. 2009;120(25):2577-585. http://doi:10.1161/CIRCULATIONAHA.109.912550.

26. Storey RF, Bliden KP, Ecob R, Karunakaran A, Butler K, Wei C, et al. Earlier recovery of platelet function after discontinuation of treatment with ticagrelor compared with clopidogrel in patients with high antiplatelet responses. J Thromb Haemost. 2011;9(9):1730-7. http://doi:10.1111/j.1538-7836.2011.04419.x.

27. Breet NJ, van Werkum JW, Bouman HJ, Kelder JC, Ruven HJ, Bal ET, et al. Comparison of platelet function tests in predicting clinical outcome in patients undergoing coronary stent implantation. JAMA. 2010;303(8):754-62. http://doi:10.1001/jama.2010.181.

28. Lordkipanidzé M, Pharand C, Nguyen TA, Schampaert E, Palisaitis DA, Diodati JG. Comparison of four tests to assess inhibition of platelet function by clopidogrel in stable coronary artery disease patients. Eur Heart J. 2008;29(23):2877-85. http://doi:10.1093/eurheartj/ehn419.

29. Bonello L, Tantry US, Marcucci R, Blindt R, Angiolillo DJ, Becker R, et al. Consensus and future directions on the definition of high ontreatment platelet reactivity to adenosine diphosphate. J Am Coll Cardiol. 2010;56(12):919-33. http://doi:10.1016/j.jacc.2010.04.047.

30. Tantry US, Bonello L, Aradi D, Price MJ, Jeong YH, Angiolillo DJ, et al. Consensus and update on the definition of on-treatment platelet reactivity to adenosine diphosphate associated with ischemia and bleeding. J Am Coll Cardiol. 2013;62(24):2261-73. http://doi:10.1016/j.jacc.2013.07.101.

31. Gimbel M, Qaderdan K, Willemsen L, Hermanides R, Bergmeijer T, de Vrey E, et al. Clopidogrel versus ticagrelor or prasugrel in patients aged 70 years or older with non-ST-elevation acute coronary syndrome (POPular AGE): the randomised, open-label, non-inferiority trial. Lancet. 2020;395(10233):1374-81. http://doi:10.1016/S0140-6736(20)30325-1.

32. Park DW, Kwon O, Jang JS, Yun SC, Park H, Kang DY, et al. Clinically significant bleeding with ticagrelor versus clopidogrel in Korean patients with acute coronary syndromes intended for invasive management: a randomized clinical trial. Circulation. 2019;140(23):1865-77. http://doi:10.1161/CIRCULATIONAHA.119.041766.

33. Zhang N, Xu W, Li O, Zhang B. The risk of dyspnea in patients treated with third-generation P2Y12 inhibitors compared with clopidogrel: a meta-analysis of randomized controlled trials. BMC Cardiovasc Disord. 2020;20(1):140. http://doi10.1186/s12872-02001419-y.

34. Husted S, Emanuelsson H, Heptinstall S, Sandset PM, Wickens M, Peters G. Pharmacodynamics, pharmacokinetics, and safety of the oral reversible P2Y12 antagonist AZD6140 with aspirin in patients with atherosclerosis: a double-blind comparison to clopidogrel with aspirin. Eur Heart J. 2006;27(9):1038-47. http://doi:10.1093/eurheartj/ehi754.

35. Cannon CP, Husted S, Harrington RA, Scirica BM, Emanuelsson H, Peters G, et al. Safety, tolerability, and initial efficacy of AZD6140, the first reversible oral adenosine diphosphate receptor antagonist, compared with clopidogrel, in patients with non-ST-segment elevation acute coronary syndrome: primary results of the DISPERSE-2 trial. J Am Coll Cardiol. 2007;50(19):1844-51. http://doi:10.1016/j.jacc.2007.07.053.

\section{Table}

Tab. 1 Characteristics of the included studies 


\begin{tabular}{|c|c|c|c|c|c|c|c|c|c|c|c|c|c|c|}
\hline Authors & $\begin{array}{c}\text { Publication } \\
\text { year }\end{array}$ & Country & $\begin{array}{c}\text { Sample } \\
\text { size } \\
\text { (I/C) }\end{array}$ & & $\begin{array}{l}\text { Follow } \\
\text { up }\end{array}$ & $\begin{array}{c}\text { Age } \\
(\mathrm{I} / \mathrm{C}, \text { years })\end{array}$ & $\begin{array}{c}\text { Male } \\
(\mathrm{I} / \mathrm{C}, \%)\end{array}$ & $\begin{array}{l}\text { Smoking } \\
(\mathrm{I} / \mathrm{C}, \%)\end{array}$ & $\begin{array}{l}\text { Hypertension } \\
\text { (I/C, \%) }\end{array}$ & $\begin{array}{l}\text { Dyslipidemia } \\
\text { (I/C, \%) }\end{array}$ & $\begin{array}{l}\text { Diabetes } \\
(\mathrm{I} / \mathrm{C}, \%)\end{array}$ & s Intervention & $\begin{array}{l}\text { HTPR } \\
\text { criteria }\end{array}$ & $\begin{array}{l}\text { Bleeding } \\
\text { criteria }\end{array}$ \\
\hline $\begin{array}{l}\text { Hiasa Y, et } \\
\text { al [14] }\end{array}$ & 2014 & $\begin{array}{l}\text { Japan/ } \\
\text { Philippines }\end{array}$ & 139 & $\begin{array}{l}3 \\
\text { months } \\
\text { post PCI } \\
\text { or ACS }\end{array}$ & $28 d$ & $63 \pm 11 / 64 \pm 10$ & $92 / 83$ & NA & $58 / 65$ & $52 / 50$ & $16 / 26$ & $45 \mathrm{mg}$ BID & - & $\overline{\text { PLATO }}$ \\
\hline $\begin{array}{l}\text { Bonaca MP, } \\
\text { et al [4] }\end{array}$ & 2015 & $\begin{array}{l}\text { United } \\
\text { Kingdom/ } \\
\text { United } \\
\text { States }\end{array}$ & 14095 & $\begin{array}{l}1 \text { to } 3 \\
\text { years } \\
\text { post } \mathrm{MI}\end{array}$ & $33 \mathrm{~m}$ & $65.2 \pm 8.4 / 65.4 \pm 8.4$ & \multicolumn{2}{|c|}{$76.4 / 76.117 .1 / 16.8$} & $77.5 / 77.5$ & $76.4 / 76.7$ & \multicolumn{2}{|c|}{ 32.8/31.860mg BID } & - & TIMI \\
\hline $\begin{array}{l}\text { LI K, et al } \\
{[15]}\end{array}$ & 2015 & China & 351 & UA & $12 \mathrm{~m}$ & $62.1 \pm 6.9 / 62.4 \pm 5.8$ & $72.2 / 72.1$ & $43.6 / 46.0$ & $53.8 / 52.3$ & $36.1 / 37.8$ & \multicolumn{2}{|c|}{ 39.8/42.345mg BID } & - & PLATO \\
\hline $\begin{array}{l}\mathrm{He} \text { M, et al } \\
{[16]}\end{array}$ & 2016 & China & 30 & SCAD & $7 d$ & $64.60 \pm 5.45$ & 63.33 & 3.33 & 90 & 13.33 & NA & 22.5mg BID & $\begin{array}{l}\text { PRU > } \\
208\end{array}$ & NA \\
\hline $\begin{array}{l}\text { Xue HJ, et al } \\
{[17]}\end{array}$ & 12016 & China & 61 & $\begin{array}{l}\text { NSTE- } \\
\text { ACS }\end{array}$ & $5 d$ & $60.35 \pm 8.59 / 59.95 \pm 9.87$ & $60 / 70$ & $25 / 50$ & $35 / 60$ & $50 / 30$ & NA & $45 \mathrm{mg}$ BID & $\begin{array}{l}\text { PRU > } \\
208\end{array}$ & PLATO \\
\hline $\begin{array}{l}\text { Li H, et al } \\
{[18]}\end{array}$ & 2016 & China & 36 & SCAD & $7 d$ & $59.3 \pm 9.8 / 57.9 \pm 12.6$ & NA & NA & NA & NA & NA & 45mg BID & - & NA \\
\hline $\begin{array}{l}\text { Storey RF, } \\
\text { et al [19] }\end{array}$ & 2016 & $\begin{array}{l}\text { United } \\
\text { Kingdom/ } \\
\text { United } \\
\text { States }\end{array}$ & 116 & $\begin{array}{l}1 \text { to } 3 \\
\text { years } \\
\text { post } \mathrm{MI}\end{array}$ & $28 d$ & $\begin{array}{c}61.3 \pm 7.0 / 57.9 \pm 12.6 \\
63.3 \pm 6.6 / 64.2 \pm 6.9\end{array}$ & $\begin{array}{c}\text { NA } \\
91 / 83\end{array}$ & $\begin{array}{l}\text { NA } \\
16 / 19\end{array}$ & $\begin{array}{c}\text { NA } \\
45 / 52\end{array}$ & $\begin{array}{l}\text { NA } \\
\text { NA }\end{array}$ & $\begin{array}{c}\text { NA } \\
35 / 11\end{array}$ & $\begin{array}{l}\text { 60mg BID } \\
60 \mathrm{mg} \text { BID }\end{array}$ & $\begin{array}{c}- \\
\text { PRU > } \\
208\end{array}$ & $\begin{array}{c}\text { NA } \\
-\end{array}$ \\
\hline $\begin{array}{l}\text { Alexopoulos } \\
\text { D, et al [20] }\end{array}$ & s 2017 & Greece & 20 & $\begin{array}{l}1 \text { to } 3 \\
\text { years } \\
\text { post } \mathrm{MI}\end{array}$ & $14 \mathrm{~d}$ & $58.5 \pm 10.2$ & 100 & 35 & NA & NA & 70 & $60 \mathrm{mg}$ BID & $\begin{array}{l}\text { PRU > } \\
208\end{array}$ & BARC \\
\hline \multirow[t]{2}{*}{$\begin{array}{l}\text { Choi KN, et } \\
\text { al [21] }\end{array}$} & 2017 & Korean & 62 & $\begin{array}{l}12 \\
\text { months } \\
\text { post PCI }\end{array}$ & $28 d$ & $63 \pm 12 / 65 \pm 7$ & $70 / 68$ & $30 / 23$ & $60 / 41$ & $5 / 18$ & $25 / 18$ & 45mg BID & $\begin{array}{c}\text { PRU > } \\
208\end{array}$ & TIMI \\
\hline & & & & & & $59 \pm 10 / 65 \pm 7$ & $95 / 68$ & $55 / 23$ & $55 / 41$ & $10 / 18$ & $20 / 18$ & 90mg QD & $\begin{array}{l}\text { PRU > } \\
208\end{array}$ & TIMI \\
\hline $\begin{array}{l}\text { Park DW, et } \\
\text { al [11] }\end{array}$ & 2018 & Korea & 60 & ACS & $30 d$ & NA & NA & NA & NA & NA & NA & $60 \mathrm{mg}$ BID & $\begin{array}{l}\text { PRU > } \\
208\end{array}$ & - \\
\hline $\begin{array}{l}\text { Orme RC, et } \\
\text { al [12] }\end{array}$ & 2018 & $\begin{array}{l}\text { United } \\
\text { Kingdom }\end{array}$ & 162 & $\begin{array}{l}\text { SCAD } \\
\text { received } \\
\text { PCI }\end{array}$ & $30 d$ & $66.9 \pm 8.6 / 64.6 \pm 8.5$ & $85 / 77$ & $11 / 12$ & $69 / 68$ & $87 / 90$ & $20 / 21$ & 60mg BID & $\begin{array}{c}\text { PRU > } \\
208\end{array}$ & PLATO \\
\hline $\begin{array}{l}\mathrm{He} \text { M, et al } \\
{[22]}\end{array}$ & 2020 & China & 36 & CCS & $7 d$ & NA & NA & NA & NA & NA & NA & 60mg QD & $\begin{array}{l}\text { PRU > } \\
235\end{array}$ & NA \\
\hline $\begin{array}{l}\text { Xue J, et al } \\
{[23]}\end{array}$ & 2020 & China & 74 & ACS & $3 \mathrm{~m}$ & NA & $55 / 50$ & $70 / 15$ & $25 / 74$ & $35 / 17$ & $85 / 19$ & $45 \mathrm{mg}$ BID & - & NA \\
\hline $\begin{array}{l}\text { Wang Y, et } \\
\text { al [24] }\end{array}$ & 2021 & China & 63 & STEMI & $6 \mathrm{~m}$ & $55.65 \pm 15.19 / 55.44 \pm 11.0$ & $83.9 / 84.4$ & NA & $61.3 / 56.3$ & NA & \multicolumn{2}{|c|}{ 25.8/28.1 45mg BID } & - & PLATO \\
\hline
\end{tabular}

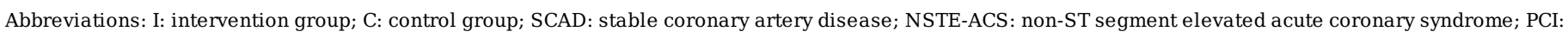

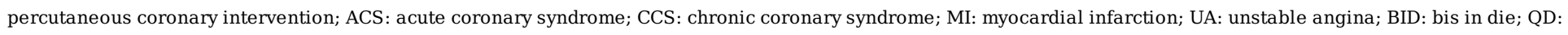

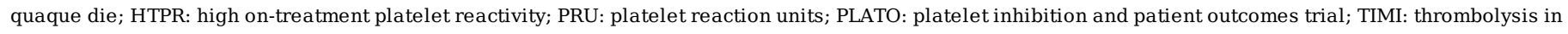
myocardial infarction; BARC: bleeding academic research consortium; NA: not available; —: no data

\section{Figures}




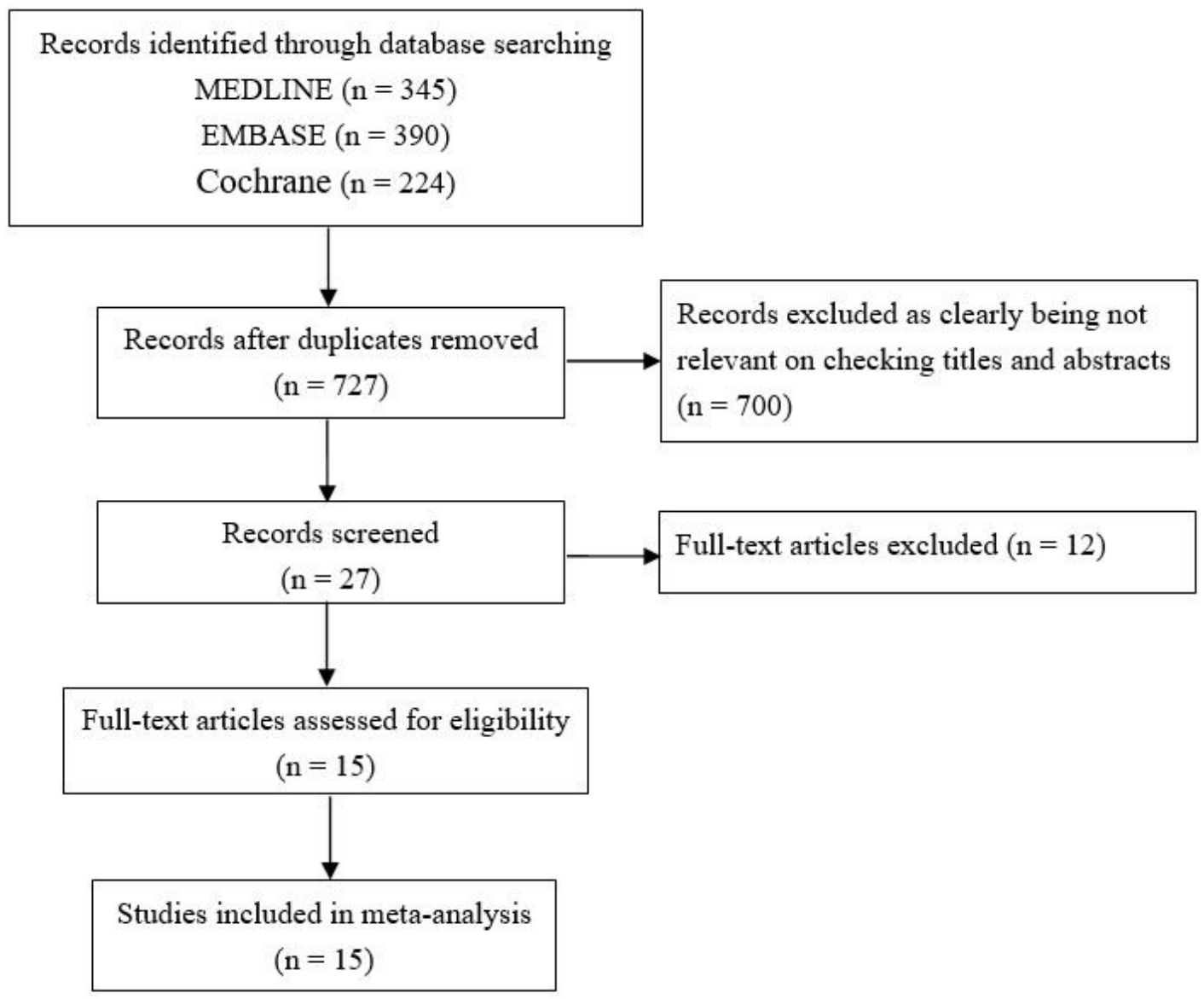

Figure 1

Study selection according to the PRISMA model

A. Low dose ticagrelor vs standard dose ticagrelor

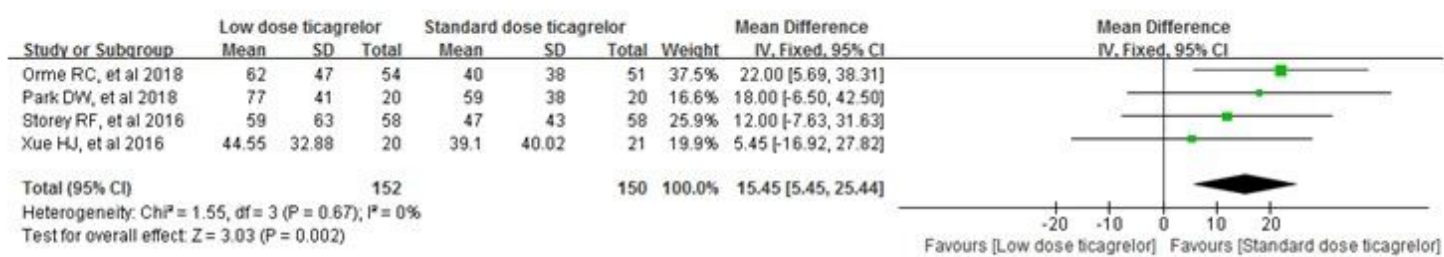

B. Low dose ticagrelor vs standard dose clopidogrel

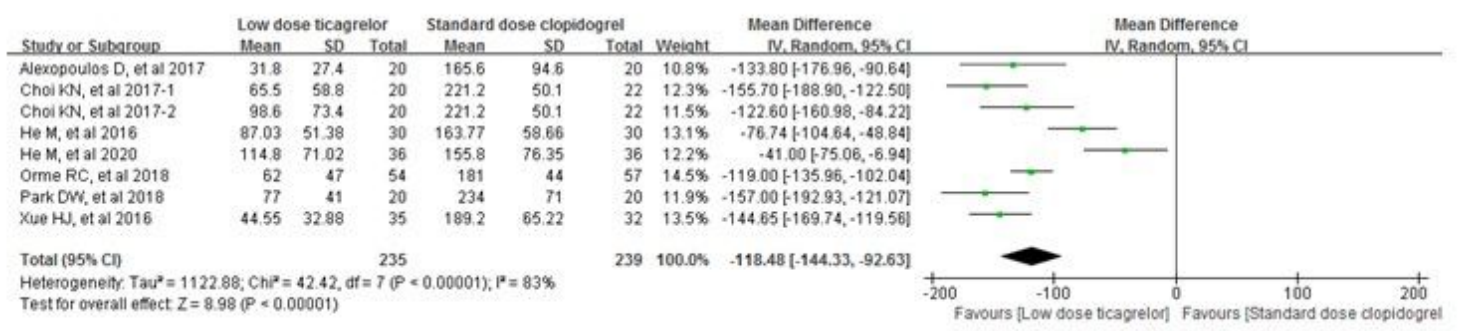

\section{Figure 2}

Forest plot of PRU 
A. Low dose ticagrelor vs standard dose ticagrelor

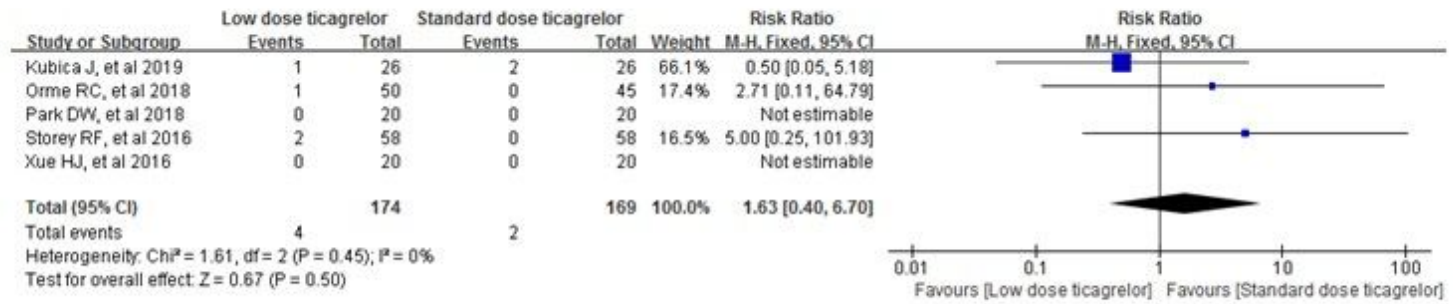

\section{B. Low dose ticagrelor vs standard dose clopidogrel}

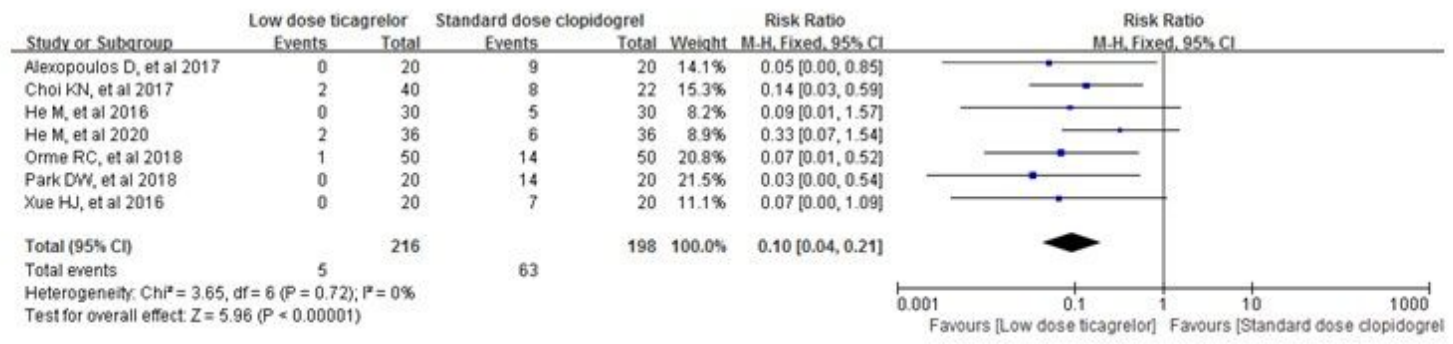

\section{Figure 3}

Forest plot of HTPR

A. Low dose ticagrelor vs standard dose ticagrelor

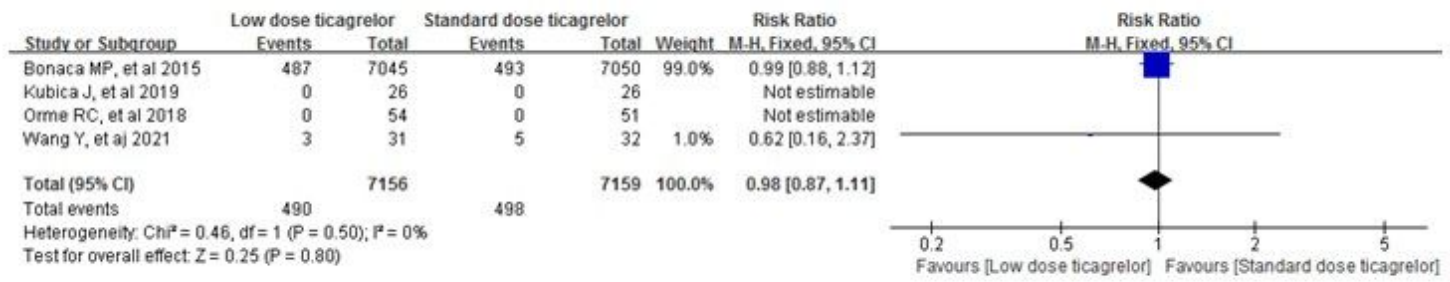

\section{B. Low dose ticagrelor vs standard dose clopidogrel}

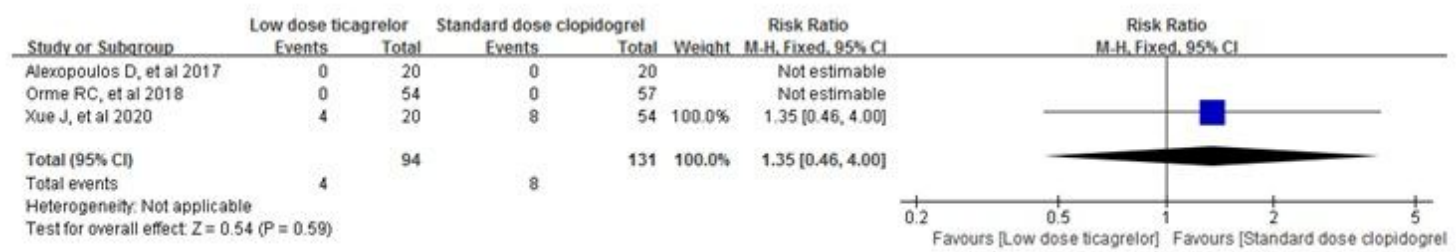

\section{Figure 4}

Forest plot of MACE 
A. Low dose ticagrelor vs standard dose ticagrelor

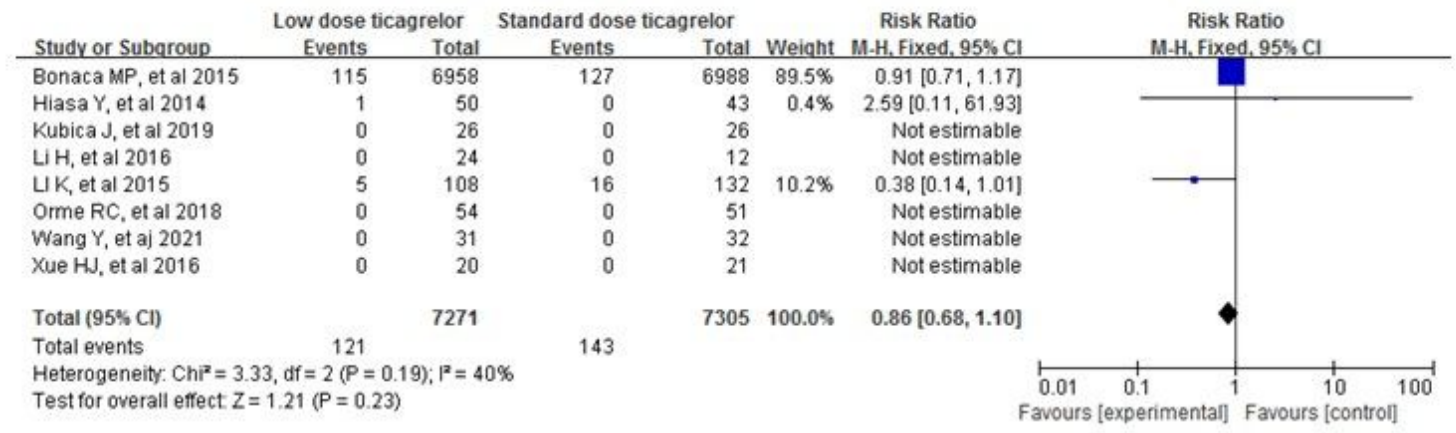

\section{B. Low dose ticagrelor vs standard dose clopidogrel}

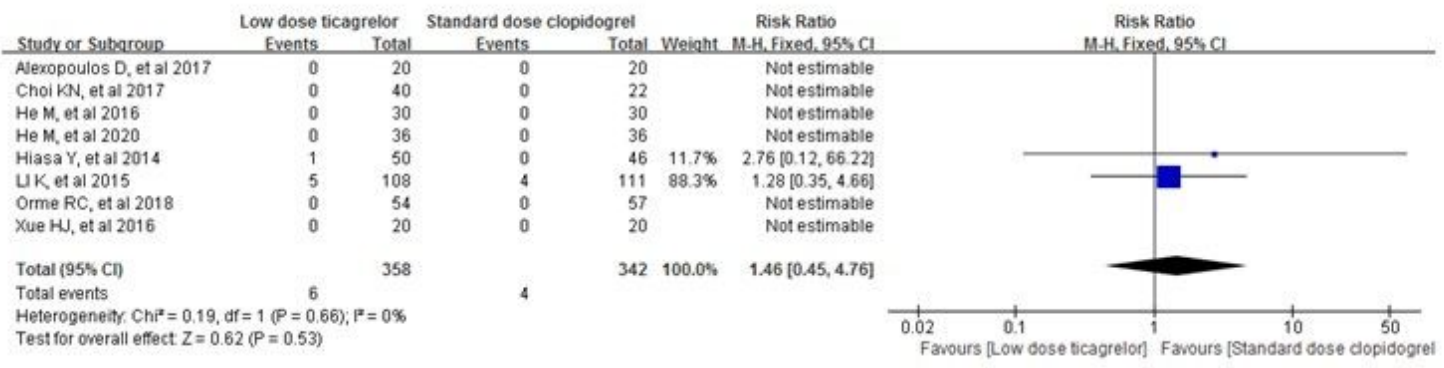

\section{Figure 5}

Forest plot of major bleeding

\section{A. Low dose ticagrelor vs standard dose ticagrelor}

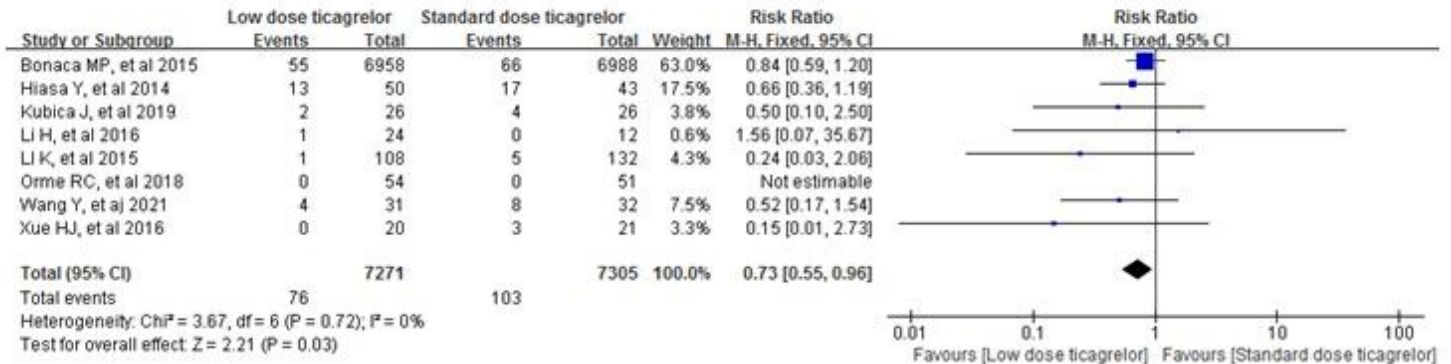

\section{B. Low dose ticagrelor vs standard dose clopidogrel}

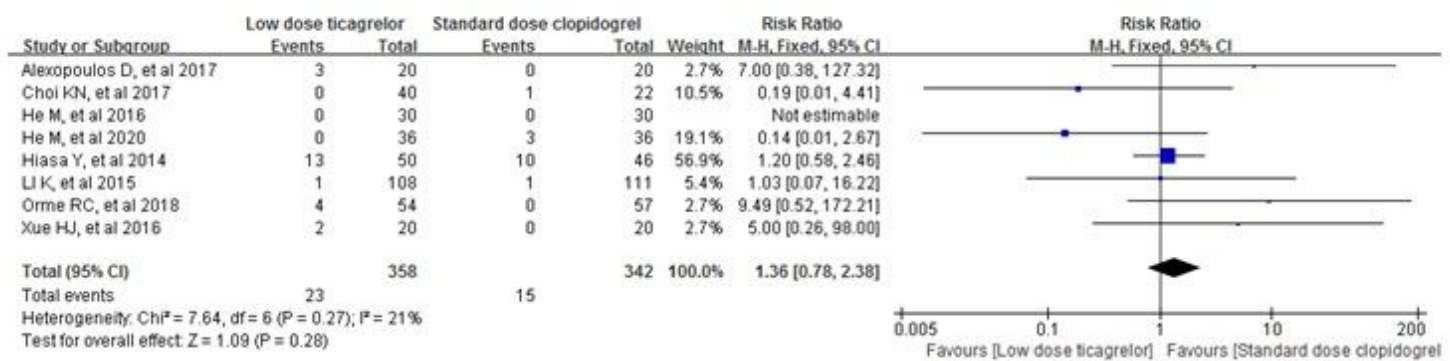

\section{Figure 6}

Forest plot of minor or minimal bleeding 
A. Low dose ticagrelor vs standard dose ticagrelor

\begin{tabular}{|c|c|c|c|c|c|c|c|c|c|c|}
\hline Studv or Subaroup & \multicolumn{2}{|c|}{ Low dose ticagrelor } & \multicolumn{2}{|c|}{ Standard dose ticagrelor } & & $\begin{array}{l}\text { Risk Ratio } \\
\text { M. H. Fixed. } 95 \mathrm{~F} \text {. I }\end{array}$ & \multicolumn{4}{|c|}{$\begin{array}{c}\text { Risk Ratio } \\
\text { M.H. Fixed, 955 CI }\end{array}$} \\
\hline Hiasa Y, et al 2014 & 0 & 50 & 2 & 43 & $0.2 \%$ & $0.17[0.01,3.50]$ & & & & \\
\hline Kubica J, et al 2019 & 2 & 26 & 2 & 26 & $0.2 \%$ & $1.00[0.15,6.57]$ & & & & \\
\hline LIK et al 2015 & 4 & 108 & 15 & 132 & $1.1 \%$ & $0.33[0.11,0.95]$ & & & & \\
\hline Orme RC, et al 2018 & 4 & 54 & 10 & 51 & $0.8 \%$ & $0.38[0.13,1.13]$ & & & & \\
\hline Wang $Y$, et aj 2021 & 1 & 31 & 4 & 32 & $0.3 \%$ & $0.26[0.03,2.18]$ & & & & \\
\hline Xue HJ, et al 2016 & 2 & 20 & 3 & 21 & $0.2 \%$ & $0.70[0.13,3.76]$ & & & & \\
\hline Total events & 1002 & & 1242 & & & & & & & \\
\hline Heterogeneity $\mathrm{Ch}^{2}=7$ & 1. $d f=7(P=$ & $P=0 \%$ & & & & & 001 & 0.1 & $i$ & $\frac{1}{10}$ \\
\hline Test for overall effect $z$ & $5.38(p<0.0$ & & & & & & & w dose tica & $\mathrm{Faw}$ & andard \\
\hline
\end{tabular}

\section{B. Low dose ticagrelor vs standard dose clopidogrel}

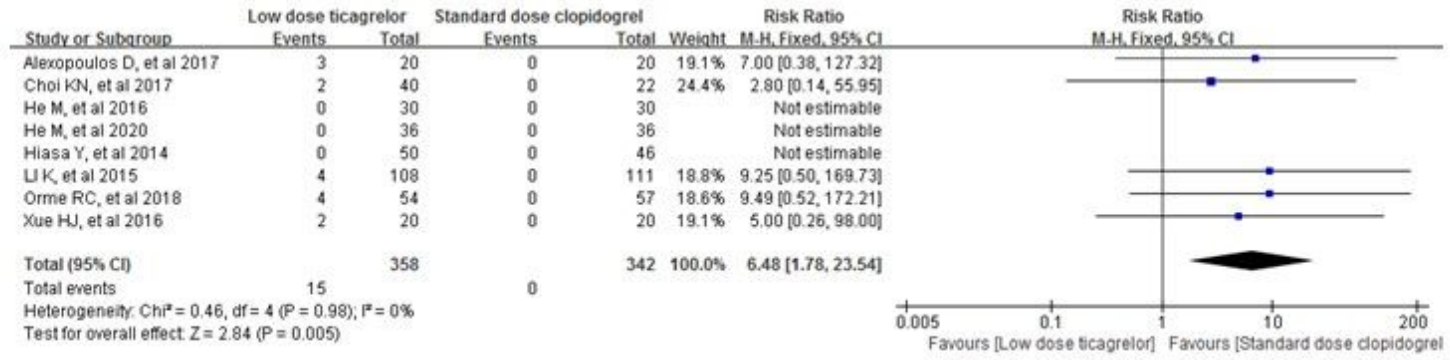

\section{Figure 7}

Forest plot of dyspnea

\section{Supplementary Files}

This is a list of supplementary files associated with this preprint. Click to download.

- Supplemental.docx 